\title{
EFFECTS OF ABIOTIC FACTORS ON FULFILLMENT OF THE POTENTIAL OF PEA CULTIVARS
}

Vasylenko A.O., Bezuglyi I.M., Shevchenko L.M., Shtelma A.M., Glyantsev A.V., Ilchenko N.K. Plant Production Institute named after V.Ya. Yuriev of NAAS, Ukraine

The results of analysis of studies carried out in the Laboratory of Peas Breeding of the Plant Production Institute named after VYa Yuriev are presented. Effects of abiotic factors on the yield and protein content in pea seeds during interphase periods are described. Determination of the effects of abiotic factors on the yield and protein content in pea seeds on average during the vegetation period does not give objective information. Determination of the effects of $\Sigma t$ and $\Sigma_{P}$ on the traits, depending on developmental phases, is more informative.

\section{Key words: pea, variety, yield, protein content, temperature, precipitation}

Introduction. The use of cultivars with high genetic potential for yield, resistant to common diseases and pests and adapted to the growing conditions in a region is the most effective and economically profitable lever of stabilization of the productivity in crop production. The creation of a cultivar, its testing and cultivation under production conditions will be occur under competing effects of abiotic factors, and interactions between these factors and the genetic system of a cultivar will determine its value.

Review of literature. Studies on a possible impact of the global warming on agriculture draw dissimilar conclusions, therefore, a high degree of uncertainty persists. A slight increase in temperature (by $1-2^{\circ} \mathrm{C}$ ) hypothetically can exert insignificant positive effects on cereal yields in middle and high latitude zones. However, these positive effects will be lost with a further increase in temperature [1].

The models applied for climate forecasting in the territory of Ukraine (PRECIS (HadRM3P), CFDL, A1B, A2, etc.) predictchanges in the average annual air temperature for the next decade all over Ukraine - from a maximum increase by $0.7^{\circ} \mathrm{C}$ to a decrease by $0.8^{\circ} \mathrm{C}$ [2-4] .According to other data, a certain drop in summer temperatures, with an increase in precipitation amount in the south-eastern region and a slight decrease in it in the northwest in the southern zones, is predicted[5].

Extension of the vegetation period, which is considered as a positive change for the regional climate, may become an illusion due to frequent and deep late spring and early autumn frosts. However, there may be conspicuous alterations in areals of actual species, and invading species, including multiple harmful and dangerous weeds, pests and pathogens, may appear and rapidly disseminate, [6].

In this context, the ability to withstand effects of environmental factors reducing performance and yield is the most important requirement for promising and new cultivars of all crops [7]. To create adaptive high-yielding cultivars, which is the primary objective for domestic breeders, analysis of resistance to abiotic factors of existing cultivars and of source material aimed at further correction of breeding programs is coming to the fore.

Some studies showed that when adaptive features of pea cultivars were determined by different methods, the same cultivars had opposite values, which confirms the necessity of comprehensive processing of research data $[8,9]$. Korobova NA et al found that cultivars with normal seeds, unlike shedding resistant accessions, were more productive, homeostatic and of higher breeding value; leafless cultivars were more susceptible to unfavorable conditions of cultivation; and leafy cultivars were the most productive $[8,10]$. Pea remains susceptible to meteorological

(C) A.O.Vasylenko, I.M. Bezuglyi, L.M. Shevchenko, A.M. Shtelma, A.V. Glyantsev, N.K. Ilchenko. 2018. ISSN 1026-9959. Селекція і насінництво. 2018. Випуск 113. 
conditions for a long time - from onset of active growth to bean filling [11]. Omelianiuk LV et al marked that both overwetting and lack absence of precipitation during mass anthesis and at the beginning of bean formation in the southern forest-steppe of the Omsk region significantly reduced the crop potential [12]. Lozhkina OV established that the performance was influenced both by varietal characteristics and by agroecological conditions, including water regime throughout the vegetation period. Mid-ripening locally-bred pea accessions with normal leaves were the most adapted to the southern forest-steppe in the Omsk region [13]. High drought-tolerance of local pea cultivars created in the Bashkir Research Institute of Agriculture (the western steppe piedmont of the Ural Mountains) by Popov BK is attributed to their biological characteristics - accelerated rate of growth and accumulation of macro nutrientsduring an extended vegetative period [14].

Summarizing the literature data $[8-10,12,13,15,16]$, we can assume that the highest performance in an area can be obtained from local cultivars and breeding material, although sometimes there are cultivars with a wide norm of reaction. Assessment of adaptability not only of one's own breeding material but also of collections allows identifying valuable genotypes of different eco-geographical origin, which are further involved in breeding [17]. However, use of nothing but high-yielding accessions upon creation of new material can lead to loss of environmental stability. Since the averages of the -susceptibility to the environment" traits are relatively independent and genetically determined separately, breeding for environmental stability should be monitored continuously [18].

Our purpose was to determine the effects of abiotic factors (temperature regime and precipitation amount) on the yield and protein content in pea cultivars.

Materials and methods. The experiments were carried out in the experimental field of the Plant Production Institute named after VYa Yuriev (PPI nd. a. VYa Yuriev) in 2008-2017. In the competitive trial, seeds were sown with a seeder "Klen" equipped with a batch apparatus. The seeding rate was 1,200,000 germinable seeds per hectare. The plot area in the competitive trial was 20 $\mathrm{m}^{2}$. The experimental variants were arranged in a random design and carried out in 4 replicas [19]. Phenological observations were conducted; uniformity of plants in the plot was evaluated.

Twenty six pea cultivars were studied; of them 19 were created in the Laboratory of Pea Breeding of the PPI nd. a. VYa Yuriev, and 7 cultivars were of different eco-geographical origin. There were 7 seven cultivars of leafy morphotype - Kharkivskyi 302, Kharkivskyi 85, Kharkivskyi Yantarnyi, Intensyvnyi 92, Rezonator, Orlovchanin, Ramonskiy 77; the others cultivars were leafless.

The Laboratory of Genetics, Biotechnology and Quality of the PPI nd. a. VYa Yuriev NAAS analyzed protein content in pea seeds on an Infralium FT-10.

The hydrothermal coefficient (HTC) was calculated, as Selianinov described [20].

The experimental data were statistically processed in standard Microsoft software, as described in [19].

Results and discussion. In the study period, the hydrothermal regime significantly fluctuated during the ontogenesis of peas plants. Thus, analyzing the temperature sum $\left(\Sigma_{t}\right)$, precipitation amount $\left(\Sigma_{\mathrm{P}}\right), \mathrm{HTC}$ and yield, we found that the smallest $\Sigma_{\mathrm{t}}$ was in 2008 and 2017 $1,003.2^{\circ} \mathrm{C}$ and $1,092.2^{\circ} \mathrm{C}$, respectively, with $\Sigma_{\mathrm{P}}$ of $119.2 \mathrm{~mm}$ in 2008 and only of $54.2 \mathrm{~mm}$ in 2017, nevertheless, the yield was the highest in $2008-4.31 \mathrm{t} /$ ha (Table 1). The largest $\Sigma_{\mathrm{t}}$ was recorded in $2013\left(1,349.2^{\circ} \mathrm{C}\right)$, with $\Sigma_{\mathrm{P}}$ of $97.1 \mathrm{~mm}$, however the yield in 2013 was the lowest during the study period $-1.45 \mathrm{t} / \mathrm{ha}$.

When we assessed the effect of $\Sigma_{\mathrm{P}}$ on the yield, we observed neither visible nor statistically significant dependencies. Thus, for example, in $2011 \Sigma_{\mathrm{P}}$ was $211.2 \mathrm{~mm}$, and the yield was 2.29 $\mathrm{t} / \mathrm{ha}$, and in 2012 and $2017 \Sigma_{\mathrm{P}}$ was $75.5 \mathrm{~mm}$ and $54.2 \mathrm{~mm}$, respectively, with higher average yields of $2.54 \mathrm{t} / \mathrm{ha}$ and $2.41 \mathrm{t} / \mathrm{ha}$, respectively.

The statistical analysis confirmed this by a negligible correlation coefficient between $\Sigma_{\mathrm{P}}$ and yield $(r=-0.10)$, and a similar insignificant coefficient was between the HTC and yield $(r=0.02)$. The correlation coefficient between $\Sigma t$ and yield $(\mathrm{r}=-0.64)$ was significant and negative; this is quite consistent with other authors'data reporting a greater impact of temperature regime during ontogenesis on the pea yield, although there is a completely opposite opinion [1, 6 (p. 257)]. 
Table 1.

Meteorological Indices and Yield in 2008-2017

\begin{tabular}{ccccc}
\hline Year & $\Sigma t,{ }^{\circ} \mathrm{C}$ & $\Sigma_{\mathrm{P}}, \mathrm{mm}$ & HTC & Yield, t/ha \\
\hline 2008 & $1,003.2$ & 119.2 & 1.19 & 4.31 \\
2009 & $1,098.5$ & 64.7 & 0.59 & 1.88 \\
2010 & $1,233.4$ & 89 & 0.72 & 1.76 \\
2011 & $1,151.5$ & 211.2 & 1.83 & 2.29 \\
2012 & $1,302.9$ & 75.5 & 0.58 & 2.54 \\
2013 & $1,349.2$ & 97.1 & 0.72 & 1.45 \\
2014 & $1,193.0$ & 226.3 & 1.90 & 1.65 \\
2015 & $1,192.9$ & 151 & 1.27 & 1.96 \\
2016 & $1,158.6$ & 135 & 1.17 & 1.83 \\
2017 & $1,092.2$ & 54.2 & 0.50 & 2.41 \\
\hline
\end{tabular}

The analysis of sowing dates and some phases of vegetation showed that the crop was sown in April throughout the study years, and, depending on the conditions of a year, shoots appeared 8-18 days later (Table 2). In general, in 2008-2017, the anthesis onset was within the first 10 days of June, except for 2014, when this phase was within the third 10 days of May.

Table 2.

Individual Phases of Pea Vegetation, 2008-2017

\begin{tabular}{ccccccc}
\hline Year & Sowing & 10 days & Sprouting & 10 days & Anthesis & 10 days \\
\hline 2008 & April 6-10 & 1.04 & April 20-23 & 3.04 & June 7-13 & 1.06 \\
2009 & April 9-12 & 1.04 & April 21-25 & 3.04 & June 1-7 & 1.06 \\
2010 & April 16-18 & 2.04 & April 29- May 1 & 3.04 & May 29- June 6 & 1.06 \\
2011 & April 22-24 & 3.04 & May 4-5 & 1.05 & June 2-10 & 1.06 \\
2012 & April 20-22 & 3.04 & April 28-30 & 3.04 & May 29- June 9 & 1.06 \\
2013 & April 21-23 & 3.04 & May 1-3 & 1.05 & May 30 - June 9 & 1.06 \\
2014 & April 7-8 & 1.04 & April 22-23 & 3.04 & May 25-31 & 3.05 \\
2015 & April 15-16 & 2.04 & April 29 & 3.04 & June 2-8 & 1.06 \\
2016 & April 12-14 & 2.04 & April 24-26 & 3.04 & June 3-10 & 1.06 \\
2017 & April 10-12 & 2.04 & April 28-30 & 3.04 & June 4-10 & 1.06 \\
\hline
\end{tabular}

Bean filling began 7-10 days after the anthesis onset, i. e., throughout the study period, except for 2014, this phase occurred within the second 10 days of June.

The average yield, protein content, their limits and variability over the study years are presented in Table 3.

Table 3.

Variability of Economically Valuable Features, 2008-2017.

\begin{tabular}{ccccc|cccc}
\hline \multirow{2}{*}{ Year } & \multicolumn{4}{c|}{ Yield, t/ha } & \multicolumn{4}{c}{ Protein content, \% } \\
\cline { 2 - 9 } & average & $\min$ & $\max$ & $\mathrm{V}, \%$ & average & $\min$ & $\max$ & $\mathrm{V}, \%$ \\
\hline 2008 & 4.31 & 3.19 & 4.80 & 9.08 & 20.44 & 17.69 & 24.89 & 8.64 \\
2009 & 1.88 & 1.55 & 2.16 & 8.60 & 22.31 & 20.43 & 24.53 & 4.74 \\
2010 & 1.76 & 1.52 & 2.16 & 8.96 & 21.88 & 19.13 & 23.99 & 6.03 \\
2011 & 2.29 & 1.59 & 2.81 & 11.86 & 21.88 & 19.36 & 24.32 & 6.41 \\
2012 & 2.54 & 1.71 & 3.08 & 10.70 & 21.23 & 18.22 & 23.43 & 5.73 \\
2013 & 1.45 & 0.92 & 2.40 & 21.23 & 21.11 & 18.22 & 23.87 & 6.50 \\
2014 & 1.65 & 0.98 & 2.69 & 26.41 & 24.04 & 22.06 & 26.01 & 4.70 \\
2015 & 1.96 & 1.23 & 2.46 & 15.19 & 23.33 & 21.32 & 25.46 & 5.04 \\
2016 & 1.83 & 1.40 & 2.42 & 14.08 & 20.92 & 19.29 & 22.83 & 4.02 \\
2017 & 2.41 & 2.14 & 2.79 & 7.74 & 17.90 & 15.59 & 20.05 & 5.37 \\
\hline
\end{tabular}


The variability range for the «yield» trait varied considerably over the study years; for example, in 2008-2010 and in 2017, it was insignificant ( $\mathrm{V}=9.08 \%, \mathrm{~V}=8.60 \%, \mathrm{~V}=8.96 \%$ and $\mathrm{V}=7.74 \%$, respectively); in 2011, 2012, 2015, and 2016, it was medium ( $\mathrm{V}=11.86 \%$, $\mathrm{V}=10.70 \%, \mathrm{~V}=15.19 \%$ and $\mathrm{V}=14,08 \%$, respectively); and in 2013 and 2014, it was significant $(\mathrm{V}=21.23 \%$ and $\mathrm{V}=26.41 \%$, respectively).

Unlike the «yield» trait, the variability range for the «protein content» trait over the study years was insignificant: $V=4.02-8.64 \%$. Such values the variation coefficient can be accounted for by low phenotypic variability of the "protein content» trait, which is encoded in the cultivargenotypes in this sample, in contrast to the variability range for the "yield» trait, which is more influenced by the vegetation conditions (each plant responds differently to this factor), and this is reflected in the overall performance of an agrocenosis.

The overall ranges of phenotypic variability over the study years for the «yield» and «protein content» traits were within $0.92 \mathrm{t} / \mathrm{ha}-4.80 \mathrm{t} / \mathrm{ha}$ and $15.59 \%-26.01 \%$, respectively. The environmental variability of the yield was within $1.45-4.31 \mathrm{t} /$ ha and of the protein content - within $17.90-24.04 \%$. The genotypic variability for the «yield» trait was within $1.85-2.42 \mathrm{t} / \mathrm{ha}$, with significant variation of the trait between cultivars ( $\mathrm{V}=31.03 \%-47.72 \%)$ (see Table 4$)$; the genotypic variability for the «protein content» trait was within $19.45 \%-23.41 \%$, with slight or medium variation $(\mathrm{V}=7.24-10.34 \%)$ (see Table 5).

Table 4

Yield Influenced by the Meteorological Indices, 2008-2017.

\begin{tabular}{|c|c|c|c|c|c|}
\hline \multirow{3}{*}{ Cultivar } & \multirow{3}{*}{ Yield, t/ha } & \multirow{3}{*}{$\mathrm{V}, \%$} & \multirow[b]{2}{*}{ Over the study years } & \multicolumn{2}{|c|}{ Developmental phases } \\
\hline & & & & $\begin{array}{l}\text { Anthesis } \\
(1.06)\end{array}$ & $\begin{array}{c}\text { Bean filling } \\
(2.06)\end{array}$ \\
\hline & & & $\Sigma t$ & $\Sigma t$ & $\Sigma_{P}$ \\
\hline Kharkivskyi 302 & 2.32 & 31.41 & -0.61 & $-0.70 *$ & $0.67^{*}$ \\
\hline Kharkivskyi 85 & 2.37 & 35.05 & -0.61 & $-0.65 *$ & $0.70^{*}$ \\
\hline Intensyvnyi 92 & 2.17 & 40.75 & $-0.66^{*}$ & -0.56 & $0.72 *$ \\
\hline Kharkivskyi Yantarnyi & 2.16 & 35.08 & -0.62 & -0.53 & $0.68 *$ \\
\hline Rezonator & 2.38 & 31.22 & -0.57 & -0.45 & 0.59 \\
\hline Vusatyi 90 & 1.85 & 38.73 & -0.56 & $-0.75 *$ & 0.48 \\
\hline Kharkivskyi Etalonnyi & 1.98 & 44.13 & $-0.65 *$ & -0.58 & 0.62 \\
\hline Modus & 2.14 & 40.35 & -0.60 & -0.56 & $0.71 *$ \\
\hline Efektnyi & 2.13 & 40.59 & -0.62 & -0.62 & $0.72 *$ \\
\hline Deviz & 2.13 & 42.58 & -0.59 & -0.61 & $0.72 *$ \\
\hline Hlians & 2.24 & 39.70 & -0.57 & -0.54 & $0.68 *$ \\
\hline Tsarevych & 2.14 & 37.26 & $-0.68^{*}$ & $-0.75^{*}$ & $0.78^{*}$ \\
\hline Oplot & 2.21 & 45.48 & $-0.65^{*}$ & $-0.70 *$ & $0.71 *$ \\
\hline Otaman & 2.09 & 41.02 & -0.57 & $-0.68 *$ & $0.72 *$ \\
\hline Mahnat & 2.32 & 36.04 & -0.62 & -0.63 & $0.69 *$ \\
\hline Chekryhinskyi & 2.14 & 47.72 & $-0.64 *$ & $-0.66^{*}$ & $0.74 *$ \\
\hline Metsenat & 2.34 & 39.72 & -0.56 & -0.49 & $0.70 *$ \\
\hline Heiser & 1.90 & 36.07 & $-0.64 *$ & $-0.64 *$ & 0.52 \\
\hline Korvet & 2.38 & 42.07 & -0.57 & -0.63 & $0.64 *$ \\
\hline Orlovchanin & 2.23 & 33.31 & -0.63 & $-0.71 *$ & $0.75^{*}$ \\
\hline Ramonskyi 77 & 2.26 & 35.28 & $-0.64 *$ & $-0.60 *$ & 0.63 \\
\hline Zekon & 2.23 & 31.03 & -0.43 & -0.58 & $0.71 *$ \\
\hline Maskara & 2.42 & 37.82 & $-0.66^{*}$ & -0.60 & $0.68^{*}$ \\
\hline Kamelot & 2.37 & 39.41 & -0.61 & -0.63 & $0.64 *$ \\
\hline Hotik & 2.27 & 32.31 & -0.63 & -0.52 & 0.63 \\
\hline Damir2 & 2.02 & 47.33 & $-0.80 *$ & $-0.75 *$ & $0.80 *$ \\
\hline $\mathrm{LSD}_{05}$ & 0.16 & - & - & - & - \\
\hline
\end{tabular}

Note. ${ }^{*}$ - significant at $5 \%$ level, $r \geq 0.64$ 
Table 5.

Protein Content in Seeds Influenced by Meteorological Indices, 2008-2017.

\begin{tabular}{|c|c|c|c|c|c|c|c|c|}
\hline \multirow{4}{*}{ Cultivar } & \multirow{4}{*}{$\begin{array}{c}\text { Protein } \\
\text { content, } \\
\%\end{array}$} & \multirow{4}{*}{$\begin{array}{l}\mathrm{V} \\
\%\end{array}$} & \multirow{3}{*}{$\begin{array}{c}\text { Average } \\
\text { over the } \\
\text { study } \\
\text { years }\end{array}$} & \multicolumn{5}{|c|}{ Developmental phases } \\
\hline & & & & \multicolumn{3}{|c|}{ Branching } & \multicolumn{2}{|c|}{ Anthesis } \\
\hline & & & & 1.05 & 1.05 & 2.05 & 1.06 & 1.06 \\
\hline & & & $\Sigma_{P}$ & $\Sigma_{P}$ & HTC & HTC & $\Sigma_{t}$ & $\Sigma_{P}$ \\
\hline Kharkivskyi 302 & 21.99 & 8.08 & 0.45 & 0.60 & 0.52 & $-0.64 *$ & $0.68^{*}$ & 0.58 \\
\hline Kharkivskyi 85 & 21.58 & 9.31 & 0.45 & $0.67 *$ & 0.63 & -0.60 & 0.44 & 0.39 \\
\hline Intensyvnyi 92 & 22.51 & 10.11 & 0.55 & 0.61 & 0.47 & -0.58 & $0.75^{*}$ & 0.59 \\
\hline $\begin{array}{c}\text { Kharkivskyi } \\
\text { Yantarnyi }\end{array}$ & 22.37 & 7.58 & 0.58 & 0.39 & 0.29 & -0.56 & 0.61 & $0.72 *$ \\
\hline Rezonator & 22.20 & 9.71 & 0.51 & $0.64 *$ & 0.45 & -0.55 & $0.87 *$ & 0.44 \\
\hline Vusatyi 90 & 23.41 & 8.81 & 0.57 & $0.71 *$ & $0.74^{*}$ & $-0.74 *$ & 0.40 & 0.41 \\
\hline $\begin{array}{c}\text { Kharkivskyi } \\
\text { Etalonnyi }\end{array}$ & 22.21 & 7.28 & $0.70^{*}$ & $0.69 *$ & 0.57 & $-0.71 *$ & $0.64 *$ & 0.45 \\
\hline Modus & 20.50 & 6.19 & 0.30 & 0.16 & -0.01 & -0.23 & $0.68 *$ & 0.50 \\
\hline Efektnyi & 20.28 & 10.13 & 0.54 & 0.58 & 0.46 & -0.61 & $0.77 *$ & $0.65^{*}$ \\
\hline Deviz & 19.86 & 7.83 & $0.69 *$ & $0.76^{*}$ & $0.65^{*}$ & -0.47 & 0.52 & 0.55 \\
\hline Hlians & 19.45 & 9.66 & 0.57 & 0.60 & 0.51 & -0.57 & 0.53 & 0.59 \\
\hline Tsarevych & 21.47 & 10.34 & 0.60 & 0.54 & 0.38 & -0.61 & $0.84^{*}$ & $0.68^{*}$ \\
\hline Oplot & 21.28 & 8.17 & $0.73 *$ & $0.78 *$ & $0.69 *$ & $-0.67 *$ & $0.65^{*}$ & 0.58 \\
\hline Otaman & 21.27 & 9.30 & $0.65 *$ & 0.58 & 0.48 & $-0.68 *$ & 0.56 & 0.52 \\
\hline Mahnat & 21.65 & 8.08 & $0.64 *$ & $0.79 *$ & $0.74 *$ & -0.60 & 0.47 & 0.50 \\
\hline Chekryhinskyi & 22.19 & 9.52 & 0.61 & $0.78 *$ & $0.70 *$ & -0.63 & 0.55 & 0.47 \\
\hline Metsenat & 19.92 & 8.01 & 0.47 & 0.45 & 0.43 & -0.62 & 0.40 & 0.59 \\
\hline Heiser & 22.71 & 7.56 & 0.28 & 0.47 & 0.44 & $-0.64 *$ & 0.46 & 0.16 \\
\hline Korvet & 21.73 & 9.67 & 0.59 & 0.55 & 0.53 & -0.43 & 0.37 & $0.70^{*}$ \\
\hline Orlovchanin & 21.44 & 9.67 & 0.38 & 0.49 & 0.37 & -0.63 & $0.70^{*}$ & 0.46 \\
\hline Ramonskyi 77 & 22.20 & 8.03 & 0.47 & 0.60 & 0.53 & $-0.66^{*}$ & $0.64^{*}$ & 0.52 \\
\hline Zekon & 22.23 & 9.35 & $0.64 *$ & 0.61 & 0.58 & -0.53 & 0.39 & $0.67^{*}$ \\
\hline Maskara & 21.70 & 8.03 & 0.56 & $0.65^{*}$ & 0.61 & $-0.67 *$ & 0.56 & 0.55 \\
\hline Kamelot & 21.29 & 10.19 & $0.64 *$ & 0.53 & 0.36 & -0.49 & $0.66^{*}$ & 0.60 \\
\hline Hotik & 21.03 & 8.22 & 0.61 & $0.74 *$ & $0.67 *$ & -0.58 & 0.46 & 0.47 \\
\hline Damir 2 & 20.63 & 7.24 & $0.65^{*}$ & 0.55 & 0.51 & $-0.70 *$ & 0.58 & $0.71^{*}$ \\
\hline $\mathrm{LSD}_{05}$ & 0.53 & - & - & - & - & - & - & - \\
\hline
\end{tabular}

Note. $*$ - significant at $5 \%$ level, $r \geq 0.64$

Over the study years, during the third 10 days of April (sprouting phase), the effects of $\Sigma_{\mathrm{P}}$ and HTC on the yield were significant in three cultivars only: Tsarevych $(r=0.65$ and $r=0.69$, respectively), Orlovchanin ( $\mathrm{r}=0.71$ and $\mathrm{r}=0.74$, respectively) and Damir $2(\mathrm{r}=0.65$ and $\mathrm{r}=$ 0.69 , respectively). During the first 10 days of May, the correlation coefficients were significantly negative for two cultivars: Intensyvnyi 92 and Damir $2(r=-0.64$ and $r=-0.68$, respectively). We observed no significant influence in the other cultivars either in April or in May.

Table 4 presents the results of correlation analysis between the «yield» trait, $\Sigma_{\mathrm{P}}$ and $\Sigma_{\mathrm{t}}$ only for the periods (10-day periods) with the largest numbers of significant indices. The correlation coefficients between the HTC and yield are not presented, because they were practically identical to the correlation coefficients between $\Sigma_{\mathrm{P}}$ and yield.

The HTC effect on the yield during the second 10 days of June (bean filling phase) was significant only in cultivar Ramon $77(\mathrm{r}=0.64)$, with $\mathrm{r}=0.63$ for $\Sigma_{\mathrm{P}}$.

It is noteworthy that the effect of $\Sigma_{t}$ on the yield during the first 10 days of June (anthesis onset) was significant in 11 cultivars, and later the situation changed, as duringthe second 10 days 
of June (bean filling) the effect of $\Sigma_{P}$ became significant in the vast majority of cultivars (20). In addition, over the study years, the effect of $\Sigma_{\mathrm{t}}$ on the yield was significant in 9 cultivars only.

Thus, it was established that on average over the study years and during the anthesis phase $\Sigma t$ negatively affected the yield with various levels of significance and that $\Sigma_{\mathrm{P}}$ during the bean filling phase significantly affected on the yield in the vast majority of cultivars.

The effect of HTC on the protein content in seeds in the study years was significant only in three cultivars-Kharkivskyi Etalonnyi, Deviz and Oplotwith $r=0.66, r=0.66$ and $r=0.69$, respectively. Kharkivskyi Yantarnyi was the only cultivar in which the protein content in seeds was affected by $\Sigma \mathrm{t}$ during the second 10 days of May $(\mathrm{r}=0.74)$.

Table 5 presents the results of correlation analysis between the «protein content in seeds» trait, $\Sigma_{\mathrm{P}}, \Sigma_{\mathrm{t}}$ and HTC for the periods (10-day periods), during which the largest numbers of significant indices was obtained.

In contrast to the «yield» trait, the protein content was significantly influenced by $\Sigma_{\mathrm{P}}$ in eight cultivars only over the study years. Among them, there were cultivars, in which $\Sigma_{\mathrm{t}}$ significantly influenced the yield over the study years - Kharkivskyi Etalonnyi, Oplot and Damir 2 (see Table 4).

The effect of $\Sigma_{\mathrm{P}}$ during the first 10 days of May on the protein content was significant in ten cultivars, and the effect of the HTC remained significant in six cultivars. During the second 10 days of May, the effect of the HTC became significant in nine cultivars, however, it changed the value from positive to negative. It should be noted that in cultivars Vusatyi 90 and Oplot the effect of HTC on the protein content persisted during the first and second 10-day periods of May.

In the first 10 days of June (anthesis onset), both $\Sigma_{\mathrm{t}}$ and $\Sigma_{\mathrm{P}}$ significantly influenced the «protein content in seeds» trait in two cultivars only - Efektnyi and Tsarevych. In 12 cultivars from the sample under investigation, the effects of $\Sigma t$ and $\Sigma_{P}$ on the protein content in seeds were insignificant. The effect of $\Sigma t$ was significant in cultivars Kharkivskyi 302, Intensyivnyi 92, Rezonator, Kharkivskyi Etalonnyi, Modus, Oplot, Orlovchanin, Ramonskyi 77 and Kamelot, and, on the contrary, in cultivars Kharkivskyi Yantarnyi, Korvet, Zekon and Damir 2 the effect of $\Sigma_{\mathrm{P}-}$ was significant. Thus, the effects of $\Sigma_{\mathrm{t}}, \Sigma_{\mathrm{P}}$ and HTC on the protein content in pea cultivars were not unidirectional, did not depend on the plant morphotype, cultivar origin and were most likely to be determined by the cultivar genotype.

Conclusions. Evaluation of the effects of the abiotic factors (HTC, $\Sigma_{\mathrm{t}}$ and $\Sigma_{\mathrm{P}}$ ) on the yield and other traits of pea starting material on average over the study periodonly gives generalized estimates. More objective information can be gained by evaluating the effects of $\Sigma_{\mathrm{t}}$ and $\Sigma_{\mathrm{P}}$ during phases of the plant development on the traits. Individual determination of susceptibility of each accession to the abiotic factors during the vegetation phases, taking into account the wide ranges of the data obtained in our study can give information on its breeding and practical value and guide its further use in breeding.

\section{References}

1. Kheberband Sh. Climate changes, agriculture and trade: what is the relationship ? Mosty. 2009; 2(5). URL: http://www.ictsd.org/bridges-news/

2. Yefimov VV, Anisimov AE. Regional simulation of the climate in Ukraine in the $21^{\text {st }}$ century. 2010. URL: http:// uhmi.org.ua/conf/climat_changes/.../Efimov_Anisimov.pdf

3. Polevoy AN, Bozhko LE, Dronova EA. Agroclimatic resources of Ukraine under climate changes. 2014. URL: http://www.elib.bsu.by/bitstream/.../3_Полевой.pdf

4. Nabyvanets $\mathrm{Yu}$. Reduction in vulnerability to extreme floods and climate changes in the Dniester River basin (Dniester - III: floods and climate). Basic research into Ukraine. 2010. URL:

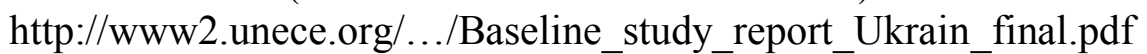

5. Ukraine's second national communication on climate changes. Kyiv, 2006. URL: https://www.journal.esco.co.ua/2006_7/art064.pdf

6. Sereda K. Climate changes (Ukraine: expectations, forecasts, prospects). Project of adaptation of the danube delta to climate changes through integrated water and land management. Marce 
2011. URL: wwf.panda.org/ru/wwf_ukraine/danube_region/dd.../progect_materials

7. Rybas IA. Increasing adaptability in cereal breeding. 2016. URL: https://cyberleninka.ru/article/v/povyshenie-adaptivnosti-v-selektsii-zernovyhkultur(15.01.2018).

8. Korobova NA, Kozlov AA, Puchkova EV. Adaptive potential of grain peavarieties. 2017. URL: $\quad$ https://cyberleninka.ru/article/v/adaptivnyy-potentsial-sortov-zernovogo-goroha (15.01.2018)

9. Katiuk AI, Zubov AE, Madiakin EV. Yield capacity and environmental plasticity of peavarieties belonging to different morphotypesduring variety changing periods. 2014. URL: https://cyberleninka.ru/article/v/urozhaynost-i-ekologicheskaya-plastichnost-sortov-goroharaznyh-morfotipov-po-periodam-sortosmeny (15.01.2018)

10. Korobova NA, Kozlov AA, Korobov AP, Puchkova EV. Environmental plasticity and yield capacity of different pea morphotypes. 2016. URL: https:// cyberleninka.ru/article/v/ekologicheskaya-plastichnost-i-urozhaynost-razlichnyh-morfotipovgoroha(15.01.2018)

11. Makasheva RKh. Pea. Grain legumes. Leneigrad: Kolos, 1979. T.IV(1). 322 p.

12. Omeljaniuk LV, Asanov AM. Performance of grain legume accessions created in the State Scientific Institution Siberian Research Institute of Agriculture and Peat, depending on the weather conditions during the vegetation period. 2013. URL: https:/cyberleninka.ru/article/v/produktivnost-obraztsov-zernobobovyh-kultur-sozdannyh-vgnu-sibniish-v-zavisimosti-ot-pogodnyh-usloviy-vegetatsionnogo-perioda (15.01.2018)

13. Lozhkina OV. Agroecological evaluation of pea accessions in the taiga zone. 2013. URL: https://cyberleninka.ru/article/n/agroekologicheskaya-otsenka-obraztsov-goroha-v-taezhnoyzone (15.01.2018)

14. Popov BK. Relative drought tolerance of pea varieties. 2011. URL: https://cyberleninka.ru/article/v/ob-otnositelnoy-zasuhoustoychivosti-sortov-zernovogogoroha (15.01.2018)

15. Prysiazhniuk OI, Korol LV. Evaluation of adaptive features of new pea varieties. 2014. URL:www.plant.gov.ua (15.01.2018)

16. Lysenko AA, Korobov AP, Shaposhnikova YuV. Influence of weather conditions on the yelds of pea varieties in the Azov zone of the Rostov region. 2017. URL: https://cyberleninka.ru/article/v/vliyanie-pogodnyh-usloviy-na-urozhaynost-sortov-goroha-vusloviyah-priazovskoy-zony-rostovskoy-oblasti(15.01.2018)

17. Vasylenko AO. Evaluation of pea breeding lines and collection accessions for adapting potential. Visnyk KhNAU. Ser. Roslynnytstvo, selektsia I nasinnytstvo, plodoovochivnytstvo. 2011; 94-100.

18. Abrosimova TN, Fadeeva AN. Adaptability and breeding value of a collection of vegetable peavarieties. 2015. URL: www.vegetable.ru/jour/article/view/92. DOI: 10.18619/2072-91462015-1-27-30 (15.01.2018)

19. Dospekhov BA. Methods of field experience. Moscow: Kolos, 1985. 351 p.

20. Tsupenko MF. Climate in Ukraine and yield: монографiя. Kyiv: Urozhay, 1975. 51 p.

\section{ВПЛИВ АБІОТИЧНИХ ЧИННИКІВ НА РЕАЛІЗАЦІЮ ПОТЕНЦІАЛУ ВРОЖАЙНОСТІ СОРТІВ ГОРОХУ}

Василенко А.О., Безуглий І.М., Шевченко Л.М., Штельма А.М., Глянцев А.В., Ільченко Н.К.

Інститут рослинництва ім. В.Я. Юр`єва НААН, Україна

Мета дослідження полягала у визначенні впливу абіотичних чинників (температурного режиму та кількості опадів) на рівень урожайності та вмісту білка в насінні сортів гороху.

Матеріали і методи. Експериментальні дослідження було проведено в 2008-2017 pp. в 
умовах дослідного поля Інститут рослинництва ім. В.Я. Юр`єва НААН (IР) згідно методиці польового експерименту. В дослідженні було використано 26 сортів гороху, серед яких 19 - селекції IP ім. В.Я. Юр`єва, сім - різного еколого-географічного походження.

Обговорення результатів. У період дослідження гідротермічний режим вегетації рослин гороху значно відрізнявся. При аналізі суми температур $(\Sigma t)$, суми опадів $(\Sigma P)$, гідротермічного коефіцієнта (ГТК) за період вегетації та врожайності за роки дослідження було встановлено, що найнижчу $\Sigma t$ було зафіксовано в 2008 р.- $1003,2{ }^{\circ} \mathrm{C}$ при $\Sigma P-$ 119,2 мм, але при цьому середній рівень урожайності був найвищим за роки дослідження $-4,31$ т/га. Найвищою $\Sigma t$ була в 2013 р.- $1349,2^{\circ} \mathrm{C}$ при $\Sigma P-97,1$ мм, але середній рівень урожайності був найнижчим - 1,45 т/га. Розрахункові коефіцієнти кореляції показали незначний рівень впливу $\Sigma P$ на врожайність $r=-0,10$, а залежність між $\Sigma t$ і врожайністю була достовірною, але оберненою $r=-0,64$.

Аналіз дати проведення сівби показав, що у всі роки його проводили у квітні, а в залежності від умов року сходи отримували через 8-18 діб. У 2008-2017 рр. початок цвітіння реєстрували в першу декаду червня, виключенням був 2014 р., коли цвітіння почалося в третій декаді травня. Формування насіння у гороху, тобто налив бобів, починається зразу після цвітіння, тому другу декаду червня взято за дату реєстрації цієї фази.

Варіювання врожайності було незначним у 2008-2010 pp. та в 2017 p. (V=9,08 \%, V = $8,60 \%, \quad \mathrm{~V}=8,96 \%$ i $\mathrm{V}=7,74 \%)$, середнім у 2011 p., 2012 p. i 2015 p., 2016 p. $(\mathrm{V}=11,86 \%, \mathrm{~V}=10,70 \%, \mathrm{~V}=15,19 \%$ i $\mathrm{V}=14,08 \%)$, а в 2013 p. і 2014 р. було на значному рівні ( $\mathrm{V}=21,23 \%$ та $\mathrm{V}=26,41 \%$ відповідно). На відміну від урожайності варіювання вмісту білка в насінні за рік дослідження було незначним і складало $\mathrm{V}=$ $4,02 \%-8,64 \%$.

Фенотиповий рівень урожайності за роки дослідження був від 0,92 т/га до 4,80 т/га, а за вмістом білка - від 15,59 \% до 26,01 \%. Середня екологічна врожайність складала 1,45 4,31 т/га, вміст білка 17,90-24,04 \%. Рівень варіювання за генотипами був від 1,85 т/га до 2,42 т/га за коефіцієнта варіації від $\mathrm{V}=31,03 \%$ до $\mathrm{V}=47,72 \%$, а за вмістом білка варіювання за генотипами було 19,45-23,41 \%, із значенням коефіцієнта варіації від $\mathrm{V}=$ $7,24 \%$ до $\mathrm{V}=10,34 \%$.

За роки дослідження істотний впливом на врожайність мала лише $\Sigma t$ для дев'яти сортів, а на вміст білка $\Sigma P$ для восьми сортів, при цьому лише для сортів Харківський еталонний, Оплот і Дамір 2 значущими були обидва чинники. Було встановлено, що на врожайність істотно впливає $\Sigma t$ у першій декаді червня (початок цвітіння) для 11 сортів, у другій декаді червня $-\Sigma P$ для більшості сортів (20 сортів). На вміст білка в насінні всіх сортів і $\Sigma P$, і $\Sigma t$, і ГТК впливали по-різному протягом усього періоду росту і розвитку рослин.

Висновки. Встановлення впливу абіотичних чинників $(\Sigma P, \Sigma t)$ і ГТК на врожайність та інші ознаки в середньому за період дослідження може бути не достатньо інформативним. Більш інформативним $є$ визначення впливу $\Sigma P i \Sigma t$ на ознаки в окремі фази вегетації.

Ключові слова: горох, урожайність, вміст білка, температура, опади

\section{ВЛИЯНИЕ АБИОТИЧЕСКИХ ФАКТОРОВ НА РЕАЛИЗАЦИЯЮ ПОТЕНЦИАЛА УРОЖАЙНОСТИ СОРТОВ ГОРОХА}

Василенко А.А., Безуглый И.Н., Шевченко Л.Н., Штельма А.М., Глянцев А.В., Ильченко Н.К.

Институт растениеводства им. В.Я. Юрьева НААН, Украина

Цель исследования состояла в определении влияния абиотических факторов (температурного режима и количества осадков) на уровень урожайности и содержания белка в семенах сортов гороха. 
Материалы и методы. Экспериментальные исследования были проведены в 2008-2017 гг. в условиях опытного поля Института растениеводства (ИР) им. В. Я. Юрьева согласно методике полевого эксперимента. Исходным материалом были 26 сортов гороха, из которых 19 - селекции ИР им. В. Я. Юрьева, семь - различного экологогеографического происхождения.

Обсуждение результатов. В период исследований гидротермический режим вегетации растений гороха значительно различался. При анализе суммы температур $(\Sigma t)$, суммы осадков $(\Sigma P)$, гидротермического коэффициента (ГТК) за период вегетации и урожайности за годы исследований было установлено, что наименьшая $\Sigma t$ была зафиксирована в 2008 г.- $1003,2^{\circ} \mathrm{C}$ при $\Sigma P-119,2$ мм. При этом средний уровень урожайности был наивысшим за годы исследований $-4,31$ т/га. Наибольшая $\Sigma t$ была в 2013 г.- $1349,2{ }^{\circ} \mathrm{C}$ при $\Sigma P-97,1$ мм, но средний уровень урожайности был самым низким - 1,45 т/га. Расчетные коэффициенты корреляции показали незначительный уровень влияния $\Sigma P$ на урожайность $r=-0,10$, а зависимость между $\Sigma t$ и урожайностью была достоверной, но обратной $r=-0,64$.

Анализ даты проведения посева показал, что во все годы его проводили в апреле, а в зависимости от условий года всходы получали через 8-18 дней. В 2008-2017 гг. начало цветения регистрировали в первую декаду июня, исключение составил 2014 г., когда цветение началось в третью декаду мая. Формирование семян у гороха, т. е. налив бобов, начинается сразу после цветения, поэтому вторая декада июня взята за дату регистрации этой фазы.

Варьирование урожайности было незначительным в 2008-2010 гг. и в 2017 г. (V=9,08 \%, $\mathrm{V}=8,60 \%, \mathrm{~V}=8,96 \%$ и $\mathrm{V}=7,74 \%$ ), средним в 2011 г., 2012 г. и 2015 г., 2016 г. $(\mathrm{V}=11,86 \%, \mathrm{~V}=10,70 \%, \mathrm{~V}=15,19 \%$ и $\mathrm{V}=14,08 \%)$, а в 2013 г. и 2014 г. было на значительном уровне ( $\mathrm{V}=21,23 \%$ та $\mathrm{V}=26,41 \%$ соответственно). В отличие от урожайности варьирование содержания белка в семенах за год исследований было незначительным и составило $\mathrm{V}=4,02-8,64 \%$.

Фенотипический уровень урожайности за годы исследований был от 0,92 т/га до 4,80 т/га, а содержание белка - от $15,59 \%$ до $26,01 \%$. Средняя экологическая урожайность составила 1,45-4,31 т/га, содержание белка 17,90-24,04 \%. Уровень варьирования по генотипам был от 1,85 т/га до 2,42 т/га при коэффициенте вариации от $\mathrm{V}=31,03 \%$ до $\mathrm{V}=$ $47,72 \%$, а по содержанию белка варьирование по генотипам было 19,45-23,41 \%, со значением коэффициента вариации от $\mathrm{V}=7,24 \%$ до $\mathrm{V}=10,34 \%$.

За годы исследований существенное влияние на урожайность оказывала только $\Sigma t$ для девяти сортов, а на содержание белка $-\Sigma P$ для восьми сортов, при этом только для сортов Харьковский эталонный, Оплот и Дамир 2 значимыми были оба фактора. Было установлено, что на урожайность оказывает существенное влияние $\Sigma t$ в первую декаду июня (начало цветения) для 11 сортов, во вторую декаду июня $-\Sigma P$ для большинства сортов (для 20 сортов). На содержание белка в семенах всех сортов и $\Sigma P$, и $\Sigma t$, и ГТК оказывали различное влияние в течение всего периода роста и развития растений.

Выводы. Определение влияния абиотических факторов $(\Sigma P, \Sigma t)$ и ГТК на урожайность и другие признаки в среднем за период исследований может быть не достаточно информативным. Более информативным будет определение влияния $\Sigma P$ и $\Sigma t$ на признаки в конкретные фазы вегетации.

Ключевые слова: горох, урожайность, содержание белка, температура, осадки 


\section{EFFECTS OF ABIOTIC FACTORS ON FULFILLMENT OF THE POTENTIAL OF PEA CULTIVARS}

Vasylenko A.O., Bezuglyi I.M., Shevchenko L.M., Shtelma A.M., Glyantsev A.V., Ilchenko N.K. Plant Production Institute named after V.Ya. Yuriev of NAAS, Ukraine

The aim and tasks of the study was to evaluate the effects of the abiotic factors (temperature regime and precipitation amount) on the yield and protein content in seeds of pea cultivars.

Materials and methods. The experiments were carried out in the experimental field of the Plant Production Institute named after VYa Yuriev (PPI nd. a. VYa Yuriev) in 2008-2017 by the field experimentation techniques. Twenty six pea cultivars were studied; of them 19 were created in the Laboratory of Pea Breeding of the PPI nd. a. VYa Yuriev, and 7 cultivars were of different eco-geographical origin.

Results and discussion. Over the study period, the hydrothermal regime during the pea vegetation considerably varied. Analyzing the temperature sum $\left(\Sigma_{t}\right)$, precipitation amount $\left(\Sigma_{\mathrm{P}}\right)$ and hydrothermal coefficient (HTC) during the vegetation period and the yield in the study years, we found that the lowest $\Sigma_{\mathrm{t}}$ was recorded in $2008\left(1003.2^{\circ} \mathrm{C}\right)$ with $\Sigma_{\mathrm{P}}$ of $119.2 \mathrm{~mm}$, however, the average yield in that year was the highest throughout the study period $-4.31 \mathrm{t} / \mathrm{ha}$. The highest $\Sigma_{\mathrm{t}}$ was noticed in $2013\left(1349.2^{\circ} \mathrm{C}\right)$ with $\Sigma_{\mathrm{P}}$ of $97.1 \mathrm{~mm}$, however, the average yield then was the lowest $-1.45 \mathrm{t} / \mathrm{ha}$. The calculated correlation coefficients showed insignificant of influence of $\Sigma_{P}$ on the yield $(\mathrm{r}=-0.10)$, and the relationship between the yield and $\Sigma_{\mathrm{t}}$ was singnificantly inverse $(\mathrm{r}=-0.64)$.

Analysis of the sowing dates showed that pea was sown in April throughout the study period, and depending on the year conditions, emergence occurred 8-18 days later. In 2008-2017, the anthesis started within the first 10 days of June, except for 2014, when the anthesis started within the third 10 days of May. Pea seed formation, i.e., bean filling, starts immediately after the anthesis, therefore, the second 10 days of June were taken as the registration date for this phase.

The yield variations were insignificant in 2008-2010 and in 2017 (V $=9.08 \%, \mathrm{~V}=8.60 \%, \mathrm{~V}=$ $8.96 \%$ and $\mathrm{V}=7.74 \%$, respectively); medium in $2011,2012,2015$, and $2016(\mathrm{~V}=11.86 \%, \mathrm{~V}$ $=10.70 \%, \mathrm{~V}=15.19 \%$, and $\mathrm{V}=14.08 \%$, respectively); and considerable in 2013 and 2014 (V $=21.23 \%$ and $\mathrm{V}=26.41 \%$, respectively). Unlike the yield, the variations in the protein content in seeds in the study year were insignificant $(\mathrm{V}=4.02-8.64 \%)$.

The yield over the study years ranged with in $0.92 \mathrm{t} / \mathrm{ha}-4.80 \mathrm{t} / \mathrm{ha}$, and the protein content - within $15.59-26.01 \%$. The average ecological yields amounted to $1.45-4.31 \mathrm{t} /$ ha, the protein content of $17.90-24.04 \%$. The variations between genotypes were within $1.85-2.42 \mathrm{t} / \mathrm{ha}$ with the variation coefficient of $31.03-47.72 \%$. The protein content between genotypes varied from $19.45 \%$ to $23.41 \%$ with the variation coefficient of $7.24-10.34 \%$.

Over the study years, $\Sigma_{\mathrm{t}}$ significantly affected the yields of nine cultivars only, and $\Sigma_{\mathrm{P}}$ significantly affected the protein content of eight cultivars. Kharkivskyi Etalonnyi, Oplot and Damir 2 were the only cultivars significantly influenced by the both factors. It was found that the yield was significantly influenced by $\Sigma_{t}$ during the first 10 days of June (anthesis onset) in 11 cultivars and by $\Sigma_{P}$ during the second 10 days of June in the majority of cultivars (20 cultivars). The protein content in seeds of all the cultivars was variously affected by $\Sigma_{\mathrm{P}}, \Sigma_{\mathrm{t}}$ and HTC throughout the whole period of plant growth and development.

Conclusions. Evaluation of the effects of the abiotic factors $\left(\Sigma_{\mathrm{P}}, \Sigma_{\mathrm{t}}\right.$ and HTC) on the yield and other traits on average over the study period may not be sufficiently informative. Evaluation of the effects of $\Sigma_{\mathrm{P}}$ and $\Sigma_{\mathrm{t}}$ during specific phases of vegetation on the traits may be more informative.

Key words: pea, variety, yield, protein content, temperature, precipitation 